\title{
Kemampuan Tumbuhan Typha Angustifolia Dalam Sistem Subsurface Flow Constructed Wetland Untuk Pengolahan Limbah Cair Industri Kerupuk (Studi Kasus Limbah Cair Sentra Industri Kerupuk Desa Kenanga Kecamatan Sindang Kabupaten Indramayu Jawa Barat)
}

\author{
Hamdani Abdulgani ${ }^{1}$, Munifatul Izzati ${ }^{2}$, Sudarno $^{3}$ \\ ${ }^{1}$ Program Studi Magister Ilmu Lingkungan, Program Pasca Sarjana Universitas Diponegoro, Semarang, Indonesia \\ ${ }^{2}$ Fakultas Sains dan Matematika Universitas Diponegoro, Semarang, Indonesia \\ ${ }^{3}$ Program Studi Teknik Lingkungan, Fakultas Teknik Universitas Diponegoro, Semarang, Indonesia \\ *Email: dani2ade@yahoo.com
}

\begin{abstract}
Industrial crackers centers at Kenanga Village has been able to lift the local economy,but that has been polluting the surrounding surface water contamination caused by wastewater discharged directly without any treatment in advance so that the water is black and smells foul. Therefore, the need of alternative wastewater treatment and in the study conducted by the artificial wetlands (constructed wetland) system Sub - surface Flow vertical flow with Typha angustifolia plant and use a medium sized sand $1 \mathrm{~mm}-5 \mathrm{~mm}$ were previously washed first with media thickness of $30 \mathrm{~cm}$ and then operated intermittently using a peristaltic pump 6 times a day with the design of constructed wetlands construction made of wood coated with plastic and reactor dimensions $90 \mathrm{~cm} \times 45$ $\mathrm{cm} \times 50 \mathrm{~cm}$. As for the control (no treatment) using use the bucket size diameter $40 \mathrm{~cm}$ and height of $20 \mathrm{~cm}$. This study aims to determine the ability of Subsurface Flow Constructed Wetland with Typha angustifolia plants in lowering the concentration of TSS, BOD, COD , ammonia $\left(\mathrm{NH}_{3}-\mathrm{N}\right)$ and sulfide $\left(\mathrm{H}_{2} \mathrm{~S}\right)$ at 5,10 and 15 days of processing. The results showed a decrease in the concentration efficiency at consecutive time 5,10 and 15 days in Subsurface Flow Constructed wetland with Typha angustifolia for TSS 73,78\%; 77,18\%; 84,71\%; BOD 5 85,83\%; 90,33\%; 94,17\%; COD 86,94\%; 90,65\%; 94,87\%; Ammonia 76,07\%; 84,25\%; 87,52\%; sulfide 94,56\%; 99,18\%; $99,81 \%$.
\end{abstract}

Keywords: Wastewater treatment, crackers industrial wastewater, Typha angustifolia plants, wetland systems.

\begin{abstract}
Abstrak
Sentra industri kerupuk di Desa Kenanga telah dapat mengangkat perekonomian masyarakat setempat, tetapi sudah menimbulkan pencemaran yaitu tercemarnya air permukaan disekitarnya yang diakibatkan oleh limbah cair yang dibuang secara langsung tanpa melalui pengolahan terlebih dahulu sehingga air berwarna hitam dan bau busuk. Oleh karena itu perlu alternatif pengolahan limbah cair dan dalam penelitian ini dilakukan dengan proses lahan basah buatan (constructed wetland) sistem Sub-surface Flow aliran vertikal dengan tumbuhan Typha angustifolia dan menggunakan media berupa pasir berukuran $1 \mathrm{~mm}-5 \mathrm{~mm}$ yang sebelumnya dicuci terlebih dahulu dengan ketebalan media $30 \mathrm{~cm}$ kemudian dioperasikan secara intermiten menggunakan pompa peristaltik 6 kali sehari dengan desain konstruksi constructed wetlands dibuat dari bahan kayu yang dilapisi dengan plastik dan berdimensi reaktor $90 \mathrm{~cm}$ x $45 \mathrm{~cm}$ x $50 \mathrm{~cm}$. Sedangkan untuk kontrol (tanpa pengolahan ) menggunakan menggunkan ember ukuran diameter $40 \mathrm{~cm}$ dan tinggi $20 \mathrm{~cm}$. Penelitian ini bertujuan untuk mengetahui kemampuan Subsurface Flow Constructed Wetland dengan tanaman Typha angustifolia dalam menurunkan konsentrasi TSS, BOD 5 , COD, Amoniak $\left(\mathrm{NH}_{3}-\mathrm{N}\right)$ dan Sulfida $\left(\mathrm{H}_{2} \mathrm{~S}\right)$ pada waktu pengolahan 5,10 dan 15 hari. Hasil penelitian menunjukkan efisiensi penurunan konsentrasi pada waktu berturut turut 5, 10 dan 15 hari pada Subsurface Flow Constructed Wetland dengan Typha angustifolia untuk TSS 73,78\%; 77,18\%; 84,71\%; BOD $_{5} 85,83 \%$; 90,33\%; 94,17\%; COD 86,94\%; 90,65\%; 94,87\%; Amoniak 76,07\%; 84,25\%; 87,52\%; Sulfida 94,56\%; 99,18\%; 99,81\%;.
\end{abstract}

Kata kunci : Pengolahan limbah cair, limbah cair industri kerupuk, Tumbuhan Typha angustifolia, system lahan basah 


\section{PENDAHULUAN}

Sentra industri kerupuk di desa Kenanga kecamatan Sindang kabupaten Indramayu telah dapat mengangkat perekonomian masyarakat di desa tersebut, namun demikian berdasarkan pengamatan di sekitar lokasi, limbah cair yang dihasilkannya telah menimbulkan pencemaran terhadap air permukaan karena limbah cair yang dihasilkannya langsung di buang ke air permukaan tanpa melalui pengolahan terlebih dahulu sehingga saluran air permukaan yang berada di sekitar lokasi sentra industri kerupuk Kenanga berwarna hitam dan bau busuk. Limbah cair indistri kerupuk yang dihasilkan merupakan sisa air pencucian ikan dan air es yang sudah mencair dari proses pembaceman ikan serta dari pencucian alat - alat produksi kerupuk, sehingga limbah cair yang dihasilkan industri kerupuk ikan merupakan limbah cair organik.

Salah satu teknologi yang dapat dapat diterapkan adalah dengan sistem lahan basah buatan atau rawa buatan (constructed wetland) yang merupakan sistem pengolahan air limbah yang menggunakan teknologi sederhana dengan pendekatan baru untuk menurunkan pencemaran lingkungan berdasarkan pemanfaatan tanaman air dan mikroorganisme. Proses pengolahan air tercemar pada rawa buatan merupakan sistem yang termasuk pengolahan alami, dimana terjadi aktivitas pengolahan sedimentasi, filtrasi, transfer gas, adsorpsi, pengolahan kimiawi dan biologis, karena aktivitas mikroorganisme dalam tanah dan aktivitas tanaman. (Metcalf dan Eddy, 1993). Keunggulan sistem ini adalah konstruksinya sederhana tanpa peralatan dan mesin, relatif murah biaya operasional, dan perawatannya, dan mempunyai kapasitas buffer yang luas dan lumpur yang dihasilkan sedikit serta stabil. (Vymazal, 2002).Selain itu pada Sistem constructed wetland dengan sistem Sub-surface Flow ini tidak beresiko langsung terhadap potensi timbulnya nyamuk karena ditutup dengan pasir (USAID, 2006)

Menurut Hammer dan Bastian (1989), bahwa suatu lahan dapat dikatakan sebagai Wetlands adalah lahan yang dapat memenuhi salah satu atau lebih dari tiga kondisi, yaitu (i) Area yang tergenangi air yang dapat mendukung kehidupan tumbuhan air sejenis hidrofita paling tidak secara periodik, (ii) Lahan yang berada dalam keadaan yang cukup basah untuk periode yang cukup panjang sehingga menimbulkan keadaan anaerob dan (iii) Lahan yang terdiri dari media bukan tanah, seperti pasir, kerikil dan batu yang jenuh dengan air atau ditutupi genangan air yang dangkal baik permanen maupun dalam beberapa waktu tertentu. Lahan basah buatan (Constructed Wetland) yang dikembangkan pada saat ini adalah sistem aliran permukaan (Free Water Surface Flow Constructed Wetland) dan sistem aliran bawah permukaan (Sub-Surface Flow Constructed Wetland) (Leady, 1997).

Dalam penelitian ini menggunakan sistem Sub-Surface Flow Constructed Wetland yang telah diteliti pada berbagai jenis pengolahan limbah cair, sedangkan jenis tumbuhan menggunakan Typha angustifolia. Tumbuhan Typha angustifolia termasuk kedalam famili Typhaceae (Cattails) yang merupakan tumbuhan rhizomatous tegak, tumbuhan menahun. Rimpang yang bercabang luas, menghasilkan tunas udara pada dan tumbuh dikedalaman yang dangkal kearah horisontal. Daun berbentuk basal tipis, tegak, linier, datar dan panjang dengan lebar 4-12 mm ketika segar dan 3$8 \mathrm{~mm}$ ketika kering dan dapat mencapai ketinggian sampai 3 meter. Bunga seperti paku besar (spike) berwarna coklat gelap berbentuk padat silinder, $15-50 \mathrm{~cm}$ yang menyatu dengan tanamannya dan dapat memproduksi hingga 200.000 bibit dengan persentase yang tinggi dari viabilitas (Prunster, 1940, Yeo, 1964). Bunga seperti paku besar tersebut berjumlah 2 bagian, yaitu bagian atas dan bawah yang dihubungkan oleh sumbu telanjang. Sumbu telanjang ini sebagai pemisah antara bunga jantan dan betina. Bunga jantan berada di bagian atas sedangkan bunga betina berada di bagian bawah. Sumbu telanjang antara bunga jantan dan betina umumnya mempunyai panjang $1-8 \mathrm{~cm}$. (USDA, NRCS, 2006)

Beberapa penelitian sebelumnya dilakukan oleh Hidayah Euis Nurul dan Wahyu Aditya (2010), dalam penelitiannya tentang pengolahan air limbah domestik dengan proses lahan basah buatan yang menggunakan tumbuhan Typha Angustifolia. Dari hasil penelitian tersebut menunjukkan bahwa tumbuhan Typha Angustifolia dalam sistem lahan basah buatan pengolahan air limbah domestik dapat penyisihan kandungan pencemar dalam air limbah dengan waktu tinggal 
3 sampai dengan 15 hari, efisiensi penyisihan COD 77,6\% - 91,8\%, BOD 47,4\% - 91,6\% dan TSS 33,3\% - 83,3\%. Sedangkan Evasari Johanna (2012), tentang pemanfaatan lahan basah buatan aliran bawah permukaan dengan menggunakan tumbuhan Typha latifolia untuk mengolah limbah cair domestik yang dilakukan skala pilot. Hasil penelitian tersebut menunjukkan bahwa tumbuhan Typha latifolia dalam lahan basah buatan aliran bawah permukaan mempunyai efektifitas penurunan COD sebesar 94\%, BOD mencapai 96,2\%, TSS mencapai 91,5\% dan MBAS mencapai $70,6 \%$.

\section{BAHAN DAN METODE}

Limbah cair industri Kerupuk yang digunakan dalam penelitian ini bersumber dari salah satu industri kerupuk di Sentra Industri Kerupuk Desa Kenanga Kecamatan Sindang Kabupaten Indramayu, yaitu Perusahaan Kerupuk Padi Kapas sedangkan media yang digunakan untuk lahan basah buatan (Constructed Wetland) berupa pasir berukuran $1 \mathrm{~mm}-5 \mathrm{~mm}$ yang sebelumnya dicuci terlebih dahulu dengan ketebalan media $30 \mathrm{~cm}$.

Sedangkan Tanaman Typha angustifolia diambil dari sekitar lokasi industri kerupuk dengan tinggi $120 \mathrm{~cm}$ dan memiliki jumlah daun 10 buah. Tanaman tersebut ditanam pada Constructed Wetland yang terbuat dari rangka kayu, dinding terbuat dari triplek dan dilapisi plastik dengan dimensi 90 × 45 x $50 \mathrm{~cm}$ dan dilengkapi dengan rangkaian pompa akuarium yang sudah diisi dengan media pasir dengan ketebalan $30 \mathrm{~cm}$ dengan jarak tanam masing - masing rumpun 15 $\mathrm{cm}$, kemudian dilakukan aklimatisasi selama 10 hari. Setelah dilakukan aklimatisasi reaktor Constructed Wetland dicuci dengan mengalirkan air bersih menggunakan pompa secara vertikal selama 30 menit pada masing-masing reaktor dan dikelurkan melalui pipa outlet.

Pengoperasian pengolahan dilakukan secara intermiten pada reaktor Vertical Subsurface Flow Constructed Wetland dengan menggunakan pompa peristaltik 6 kali sehari, masing-masing selama 30 menit. Untuk reaktor kontrol menggunkan ember ukuran diameter $40 \mathrm{~cm}$ dan tinggi $20 \mathrm{~cm}$ dalam hal ini untuk menampung limbah cair tanpa perlakuan. Variabel yang diteliti adalah konsentrasi TSS (Total Suspended Solid), Chemical Oxygen Demand (COD), Biological Oxygen Demand (BOD), Amoniak $\left(\mathrm{NH}_{3}-\mathrm{N}\right)$ dan Sulfida $\left(\mathrm{H}_{2} \mathrm{~S}\right)$ dengan waktu tinggal $0,5,10$ dan 15 hari Sedangkan pengukuran $\mathrm{pH}$ dilakukan setiap hari.

\section{HASIL DAN PEMBAHASAN \\ 1.1.Kondisi Awal Limbah Cair Industri Kerupuk}

Kondisi awal (0 hari) limbah cair industri kerupuk yang diambil dari Perusahaan Padi Kapas secara fisik berwarna hitam dan berbau busuk dengan konsentrasi pH, TSS, BOD, COD, $\mathrm{NH}_{3}$, dan $\mathrm{H}_{2} \mathrm{~S}$ adalah tercantum dalam Tabel 1 sebagai berikut :

Tabel 1. Kondisi Awal Kualitas Air Limbah Industri Kerupuk Padi Kapas Desa Kenanga Kecamatan Sindang Kabupaten Indramayu

\begin{tabular}{clccc}
\hline NO. & \multicolumn{1}{c}{ PARAMETER } & \multirow{2}{*}{ SATUAN } & $\begin{array}{c}\text { BAKU } \\
\text { MUTU }\end{array}$ & $\begin{array}{c}\text { HASIL } \\
\text { PENGUJIAN }\end{array}$ \\
\hline 1 & $\mathrm{pH}$ & & $6-9$ & 6,3 \\
\hline 2 & Total Suspended Solid $(\mathrm{TSS})$ & $\mathrm{mg} / \mathrm{L}$ & 200 & 314 \\
\hline 3 & $\mathrm{BOD}_{5}$ & $\mathrm{mg} / \mathrm{L}$ & 50 & 2.000 \\
\hline 4 & $\mathrm{COD}$ & $\mathrm{mg} / \mathrm{L}$ & 100 & $3.544,42$ \\
\hline 5 & Amoniak $\left(\mathrm{NH}_{3}-\mathrm{N}\right)$ & $\mathrm{mg} / \mathrm{L}$ & 1,0 & 22,30 \\
\hline 6 & Sulfida $\left(\mathrm{H}_{2} \mathrm{~S}\right)$ & $\mathrm{mg} / \mathrm{L}$ & 0,05 & 4,47 \\
\hline
\end{tabular}

Sumber : Hasil analisis air limbah pada tanggal 20 Agustus 2013

Dari kondisi awal limbah cair industri kerupuk diatas, jika dibandingkan dengan baku mutu berdasarkan Keputusan Menteri Lingkungan Hidup Nomor 51/MENLH/10/1995 tentang Baku 
Mutu Air limbah Industri Lainnya maka untuk kandungan Suspended Solid menunjukkan 57\% lebih besar dari baku mutu. Material tersuspensi ini mempunyai efek yang kurang baik terhadap kualitas air karena menyebabkan kekeruhan dan mengurangi cahaya yang dapat masuk ke dalam air, sehingga proses fotosintesis dan visibilitas di perairan akan terganggu. Apabila jumlah materi tersuspensi ini mengendap, maka akan mempercepat pendangkalan pada saluran.(Soemirat, 1994) dapat menyebabkan sedimen/endapan pada saluran air.

Konsentrasi BOD yang terkandung dalam air limbah industri kerupuk berdasarkan hasil analisis laboratorium pada tabel 1 adalah 2.000 mg/l. Hasil tersebut lebih besar 39 kali dari baku mutu. Sedangkan untuk konsentrasi COD lebih besar 34,4 kali dari baku mutu. Dengan konsentrasi BOD dan COD yang besar menunjukkan bahwa kandungan bahan organik pada air limbah industri kerupuk adalah besar dan menurut Rump dan Krist dalam Effiendi, $H$. (2003), merupakan air limbah dengan tingkat pencemaran berat.

Hasil analisis konsentrasi amoniak $\left(\mathrm{NH}_{3}-\mathrm{N}\right)$ air limbah industri kerupuk sebesar 22,30 mg/l atau lebih besar 21,3 kali dari baku mutu. Senyawa amoniak $\left(\mathrm{NH}_{3}\right)$ merupakan senyawa alkali yang berupa gas tidak berwarna dan larut dalam air. Amoniak berasal dari penurunan zat organik (HCONS) secara mikrobiologis (Hammer, 1996). Kadar $\mathrm{NH}_{3}$ di dalam air selalu menunjukkan adanya pencemaran dari segi estetika, amoniak mempunyai rasa kurang enak dan bau yang menyengat (Alaerts dan Santika, 1987). Tingginya senyawa amoniak $\left(\mathrm{NH}_{3}-\mathrm{N}\right)$ yang terkandung dalam air limbah industri kerupuk ini dimungkinkan bersumber dari molekul protein yang terkandung dalam bahan organik dalam limbah tersebut yang diurai oleh bakteri melalui proses amonifikasi.

Sementara itu kandungan gas hidrogen sulfida $\left(\mathrm{H}_{2} \mathrm{~S}\right)$ didalam air limbah merupakan gas berbau busuk yang dihasilkan dari proses penguraian senyawa belerang dari bahan organik oleh bakteri anaerob yang terjadi pada air tercemar yang tidak mengandung oksigen terlarut. Proses anaerob ini biasanya terjadi di perairan yang airnya tidak bersirkulasi dan tidak mempunyai kontak langsung dengan udara sehingga mengurangi kemampuan air untuk melarutkan oksigen. Semakin berat tingkat pencemaran air maka oksigen terlarut semakin sedikit begitu juga dengan jenis organisme aerobnya. Ketika oksigen terlarut tidak tersedia lagi maka penguraian bahan organik akan dilakukan oleh mikroorganisme anaerob yang mengeluarkan gas asam sulfida $\left(\mathrm{H}_{2} \mathrm{~S}\right)$ dan gas metana $\left(\mathrm{CH}_{4}\right)$. (Khiatuddin, 2003). Konsentrasi hidrogen sulfida yang terkandung di dalam air limbah industri kerupuk lebih tinggi 88,4 kali dari baku mutu. Tingginya konsentrasi sulfida $\left(\mathrm{H}_{2} \mathrm{~S}\right)$ pada air limbah industri kerupuk tersebut menunjukkan bahwa adanya proses degradasi bahan organik secara anaerob.

\subsection{Perubahan Warna}

Warna air limbah pada hari ke-5, 10 dan 15 mengalami perubahan. Pada hari ke-5 warna air limbah industri kerupuk tanpa pengolahan (kontrol) berwarna hitam kecoklatan sedangkan pada pengolahan dengan sistem Vertical Subsurface Flow Constructed Wetland dengan tumbuhan Typha angustifolia berwarna coklat pias, dan pada hari ke-10, warna pada tanpa pengolahan (kontrol) masih terlihat hitam kecoklatan sedangkan pada air limbah dengan pengolahan sistem Vertical Subsurface Flow Constructed Wetland dengan tumbuhan Typha angustifolia warna coklat mulai memudar. Perubahan warna menjadi coklat terjadi pada tanpa pengolahan (kontrol) pada hari ke-15, sedangkan warna air limbah pada Pengolahan sistem Vertical Subsurface Flow Constructed Wetland dengan Typha angustifolia terlihat jernih. Perubahan warna tersebut dapat dilihat dalam gambar 1, berikut ini : 


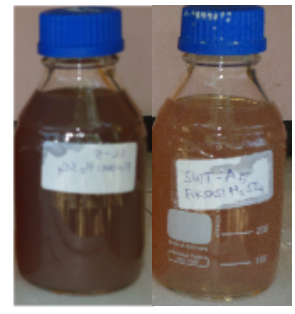

(i)
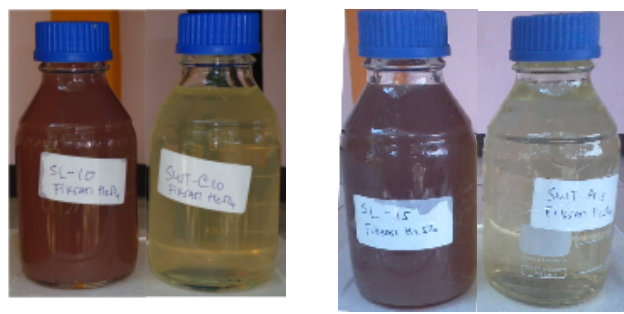

(ii)

Hari ke-5

Gambar 1 Perubahan Warna Air limbah Industri Kerupuk

Keterangan :

(i) = Tanpa Pengolahan (Kontrol)

(ii) = Pengolahan Vertical Subsurface Flow Constructed Wetland dengan tumbuhan Typha angustifolia

\subsection{Nilai pH}

Nilai pH pada air limbah industri kerupuk selama penelitian menunjukkan netral, yaitu rata rata 6,3 - 6,84. Dengan adanya Pengolahan Vertical Subsurface Flow Constructed Wetland dengan tumbuhan Typha angustifolia (VSF-
$\mathrm{CW}+$ Typha) nilai $\mathrm{pH}$ tidak mengalami kenaikan maupun penurunan yang signifikan. Dengan Nilai $\mathrm{pH}$ air limbah yang netral maka proses fotosintesis dapat berjalan dengan baik. Hasil pengukuran $\mathrm{pH}$ dapat dilihat dalam gambar 2 berikut ini :.

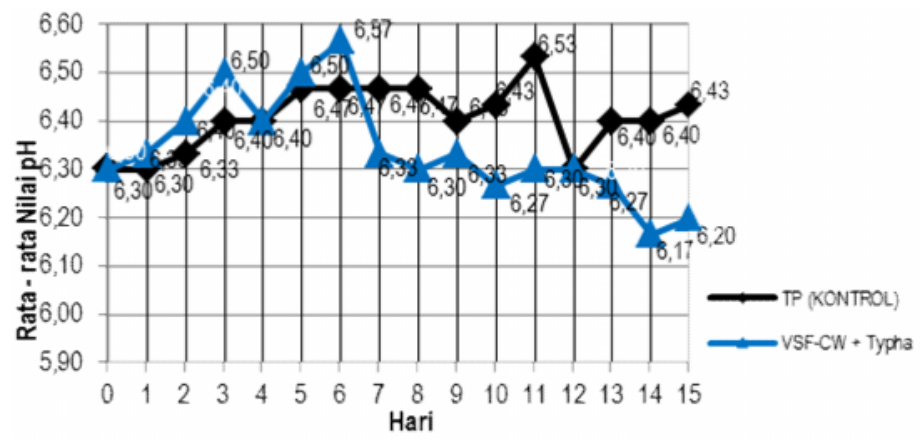

Gambar 2 Grafik Rata - Rata Nilai pH Air limbah Industri Kerupuk

\subsection{Penurunan TSS}

Hasil penelitian menunjukkan konsentrasi awal TSS pada air limbah industri kerupuk sebesar $314 \mathrm{mg} / \mathrm{l}$. Konsentrasi TSS tersebut mengalami penurunan pada waktu pengolahan 5, 10 dan 15 hari, yaitu pada tanpa pengolahan (Kontrol) rata rata $293,33 \mathrm{mg} / \mathrm{l} ; 197,67 \mathrm{mg} / \mathrm{l}$ dan $180 \mathrm{mg} / \mathrm{l}$.
Sedangkan penurunan TSS pada pengolahan sistem Vertical Subsurface Flow Constructed Wetland dengan tumbuhan Typha angustifolia (VSF-CW+Typha), yaitu rata - rata $82,33 \mathrm{mg} / \mathrm{l}$; $71,67 \mathrm{mg} / \mathrm{l}$ dan $48 \mathrm{mg} / \mathrm{l}$. Grafik penurunan konsentrasi dan efisiensi TSS tersaji dalam gambar 3 ,dan 4,sebagai berikut 

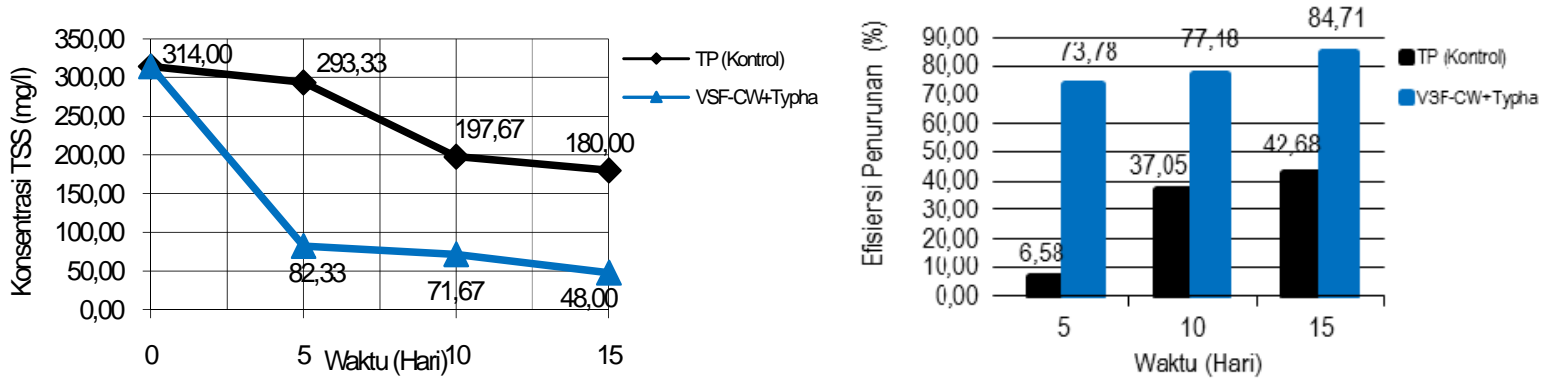

Gambar 3 Grafik Rata - Rata Penurunan Konsentrasi TSS

Dari gambar 4 menunjukkan bahwa penurunan konsentrasi Suspended Solid (SS) pada air limbah industri kerupuk, dapat terjadi meskipun tanpa perlakukan. Efisiensi penurunan SS pada tanpa pengolahan (Kontrol) dengan efisiensi penurunan makin meningkat seiring dengan lamanya waktu tinggal. Pada waktu tinggal 5, 10 dan 15 hari berturut - turut adalah 6,58\%; $37,05 \%$ dan $42,68 \%$, hal ini diakibatkan karena adanya proses sedimentasi yang dipengaruhi oleh gravitasi bumi sehingga semakin lama waktu tinggal, maka kesempatan SS untuk mengendap makin lama dan makin banyak.

Pada perlakuan Constructed Wetland dengan tumbuhan Typha angustifolia (VSF$\mathrm{CW}+$ Typha), efisiensi penurunan SS cenderung meningkat seiring dengan lamanya waktu tinggal, yaitu sebesar $73,78 \%$; 77,18\% ; 84,71\% pada waktu 5, 10 dan 15 hari, hal ini dimungkinkan oleh adanya proses penyaringan SS dan dengan adanya pengoperasian sirkulasi maka penyaringan SS dapat terjadi secara berulang - ulang. ini terjadi karena selain terjadinya penyaringan Suspended Solid (SS) secara mekanis ketika air limbah tersebut melewati media/substrat, juga terjadi penyaringan oleh massa akar atau fauna air (Stowell,et al, 1980). Dengan terjadinya penurunan SS ini, maka akan mengurangi kebutuhan oksigen terlarut pada pengolahan biologis berikutnya.

\subsection{Penurunan $\mathrm{BOD}_{5}$}

Berdasarkan hasil pengujian laboratorium konsentrasi awal $\mathrm{BOD}_{5}$ air limbah industri kerupuk sebesar $2.000 \mathrm{mg} / \mathrm{l}$. Pada tanpa pengolahan (Kontrol) konsentrasi $\mathrm{BOD}_{5}$ turun menjadi rata - rata $1.694 \mathrm{mg} / \mathrm{l}$ (5 hari); 1.042,67 $\mathrm{mg} / \mathrm{l}$ (10 hari) dan 541,33 mg/l (15 hari). Pada sistem Vertical Subsurface Flow Constructed Wetland dengan tumbuhan Typha angustifolia (VSF-CW+Typha) konsentrasi $\mathrm{BOD}_{5}$ dapat diturunkan rata - rata menjadi $283,33 \mathrm{mg} / \mathrm{l}$ (5 hari); $193,33 \mathrm{mg} / \mathrm{l}$ (10 hari) dan 116,67 mg/l (15 hari). Penurunan konsentrasi $\mathrm{BOD}_{5}$ pada masing masing pengolahan dapat dilihat dalam gambar 5 di bawah ini : 

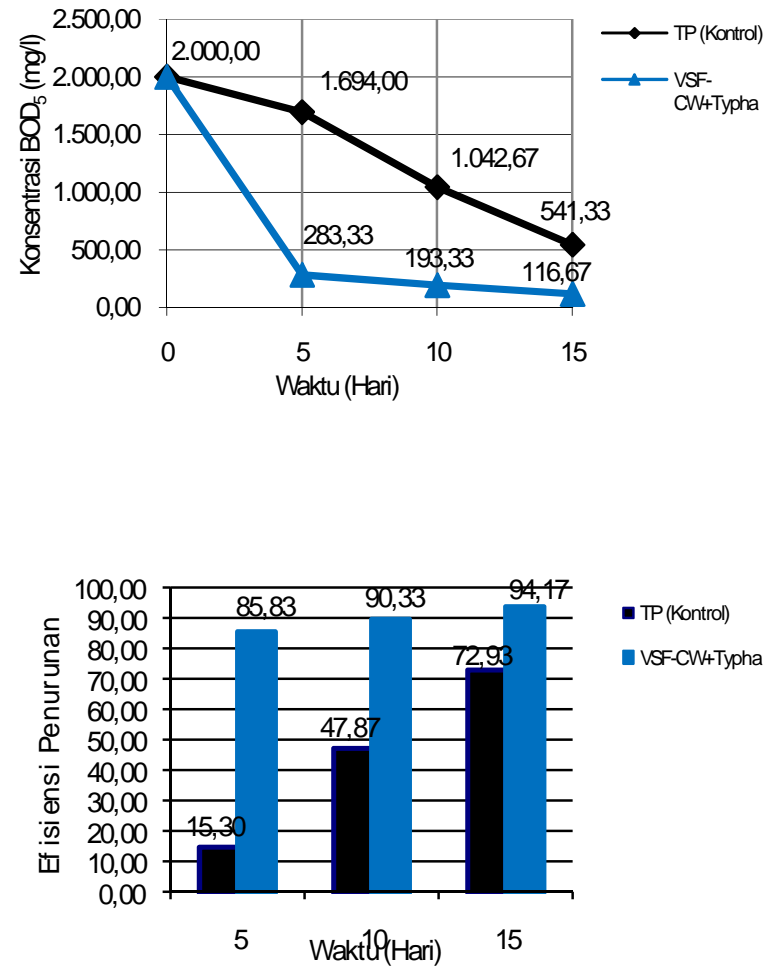

Gambar 5, 6 Penurunan Konsentrasi BOD5 pada masing masing pengolahan

Berdasarkan gambar 6 diatas menunjukkan bahwa penurunan konsentrasi $\mathrm{BOD}_{5}$ semakin meningkat seiring dengan bertambahnya waktu pengolahan. Pada tanpa pengolahan (Kontrol) konsentrasi $\mathrm{BOD}_{5}$ dapat menurunkan sebesar $15,30 \%$ ( 5 hari); 47,87\% (10 hari) dan 72,93\% (15 hari). Hal ini terjadi karena adanya proses degradasi zat pencemar organik oleh mikroorganisme secara aerob yang membutuhkan oksigen terlarut. Sumber oksigen terlarut tersebut bersumber dari udara yang masuk kedalam air limbah karena media penampung air limbah memiliki kedalaman $20 \mathrm{~cm}$ sehingga sinar matahari dan oksigen dari udara dapat masuk kedalam air limbah. Sedangkan mikroorganisme pengurai zat organik bersumber dari air limbah industri kerupuk yang tersuspensi dalam air limbah. Pertumbuhan tersuspensi mikroorganisme tumbuh dan berkembang dalam keadaan tersuspensi secara menyeluruh dalam air limbah.

Pada perlakuan Vertical Subsurface Flow Constructed Wetland dengan tumbuhan Typha angustifolia (VSF-CW+ Typha) penurunan $\mathrm{BOD}_{5}$ berturut - turut pada hari ke-5, 10 dan 15 adalah 85,83\%; 90,33\% dan 94,17\%. Penurunan $\mathrm{BOD}_{5}$ terjadi karena adanya proses degradasi zat pencemar organik oleh mikroorganisme secara aerob yang membutuhkan oksigen terlarut. Untuk oksigen terlarut pada pengolahan ini bersumber dari udara yang masuk ke dalam air limbah sebagai oksigen terlarut melalui pengoperasian sirkulasi air limbah secara intermiten selama 30 menit dengan menggunakan pompa peristaltik 6 kali sehari. Dengan bertambahnya waktu tinggal maka ketersediaan oksigen untuk proses biologis makin banyak pula. Pada pengolahan Vertical Subsurface Flow Constructed Wetland dengan tumbuhan Typha angustifolia (VSF-CW+ Typha) ini terdapat media isian bahan padat (pasir) yang menyebabkan mikroorganisme yang terlibat tumbuh dan melekat atau membentuk lapisan tipis (biofilm) pada permukaan media (MetCalf dan Eddy, 2003). Dengan demikian air limbah industri kerupuk yang dialirkan melalui media tempat tumbuhnya mikroorganisme sebagai biofilter akan menghasilkan lapisan lendir yang menutupi media tumbuh atau disebut biological film dan akan mengalami proses penguraian secara biologis. Menurut Wood dalam Tangahu dan Warmadewanthi (2001) bahwa penurunan zat organik dalam sistem lahan basah buatan terjadi karena adanya mekanisme aktivitas mikroorganisme dan tumbuhan, melalui proses oksidasi oleh bakteri aerob yang tumbuh disekitar rizhosfer tumbuhan maupun kehadiran bakteri heterotrof dalam air limbah.

Menurut Khiatuddin (2003) bahwa semakin banyak jaringan akar dalam tanah, maka makin luas zona rizhosfer yang terbentuk, sehingga kemampuan rawa untuk mendukung mikroorganisme semakin meningkat. Penurunan kandungan BOD dalam proses Constructed Wetland sangat membutuhkan ketersediaan oksigen terlarut yang cukup yang akan dilepaskan oleh akar tumbuhan didalam zona izhosfer untuk mikroorganisme dalam menguraikan zat - zat organik yang kandungan dalam limbah. 


\subsection{Penurunan COD}

Konsentrasi COD awal sebelum pengolahan menunjukkan hasil sebesar 3.544,42 mg/l. Dengan adanya pengolahan dan waktu pengolahan, konsentrasi COD mengalami penurunan. Pada tanpa pengolahan (Kontrol) COD rata - rata turun menjadi $2.977,20 \mathrm{mg} / \mathrm{l}$ (5 hari); 1.852,39 mg/l (10 hari) dan $810 \mathrm{mg} / \mathrm{l}$ (15 hari), sedangkan pada pengolahan Vertical Subsurface Flow Constructed
Wetland dengan tumbuhan Typha angustifolia (VSF-CW+ Typha) menunjukkan konsentrasi COD mengalami penurunan, yaitu berturut - turut pada waktu pengolahan 5,10 dan 15 hari adalah $462,99 \mathrm{mg} / \mathrm{l} ; 331,57 \mathrm{mg} / \mathrm{l}$ dan 181,88 mg/l. Pada gambar 7 menunjukkan penurunan konsentrasi COD berdasarkan pengolahan dan waktu pengolahan.
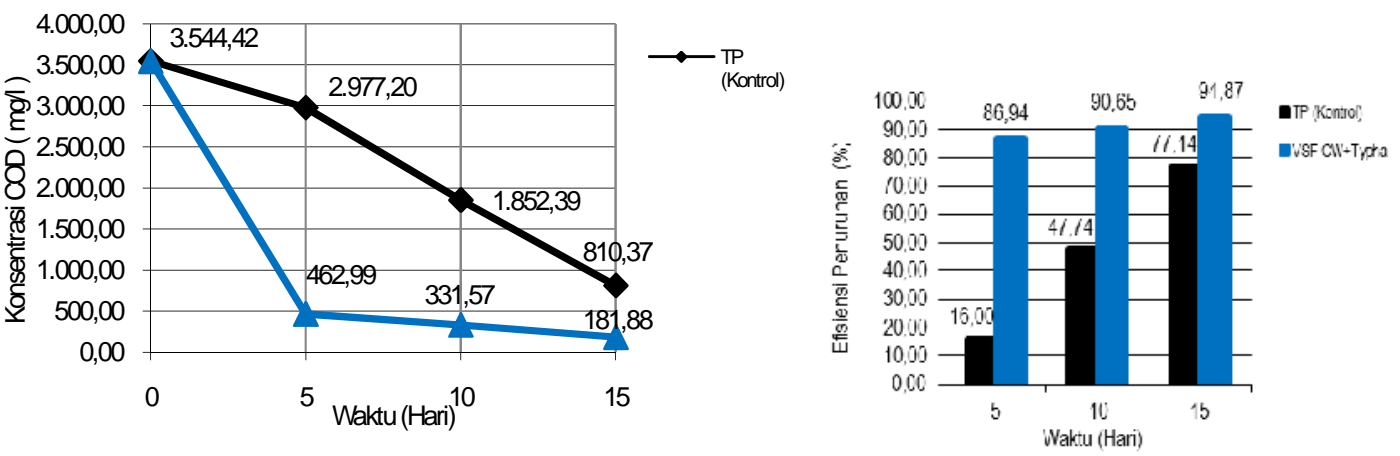

Gambar 7, 8 Penurunan Konsentrasi COD berdasarkan Pengolahan dan Waktu

Pada gambar 8 menunjukkan bahwa penurunan COD pada tanpa pengolahan (Kontrol) sebesar 16,00\% (5 hari) ; 47,74\% (10 hari); $77,14 \%$ (15 hari), sedangkan pada Sistem Vertical Subsurface Flow Constructed Wetland dengan Typha angustifolia (VSF-CW+Typha) sebesar 86,94\%; 90,65\% dan 94,87\%. Penurunan COD makin meningkat seiring dengan bertambahnya waktu pengolahan, dimana waktu detensi yang cukup akan memberikan kesempatan kontak antara mikroorganisme dengan air limbah (Wood dalam Supradata, 2005). Bahan organik yang terdapat didalam air limbah akan dirombak oleh mikroorganisme menjadi senyawa lebih sederhana dan akan dimanfaatkan oleh tumbuhan sebagai nutrien, sedangkan sistem perakaran tumbuhan air akan menghasilkan oksigen yang dapat digunakan sebagai sumber energi/katalis untuk rangkaian proses metabolisme bagi kehidupan mikroorganisme (Supradata, 2005). Jika hasil penurunan konsentrasi COD dikaitkan dengan hasil penurunan BOD, maka mengalami kecenderungan penurunan yang sama, hal ini mengidentifikasikan bahwa zat organik yang terkandung dalam air limbah industri kerupuk sebagian besar merupakan zat organik yang dapat terdegradasi secara biologis (biodegradable).

\subsection{Penurunan Amoniak}

Konsentrasi amoniak yang terkandung air limbah industri kerupuk pada kondisi awal sebesar 22,30 mg/l. Dengan waktu pengolahan 5, 10 dan 15 hari, mengalami penurunan pada tanpa pengolahan (Kontrol), yaitu rata - rata menjadi $18,47 \mathrm{mg} / \mathrm{l} ; 10,29 \mathrm{mg} / \mathrm{l}$ dan 7,03 mg/l. Sedangkan pada pengolahan Sistem Vertical Subsurface Flow Constructed Wetland dengan Typha angustifolia (VSF-CW+Typha), konsentrasi $\mathrm{NH}_{3}-\mathrm{N}$ rata - rata turun menjadi 5,34 mg/l; 3,51 mg/l dan 2,78 mg/l. Penurunan konsentrasi $\mathrm{NH}_{3}-\mathrm{N}$ ditunjukkan pada gambar 9. 

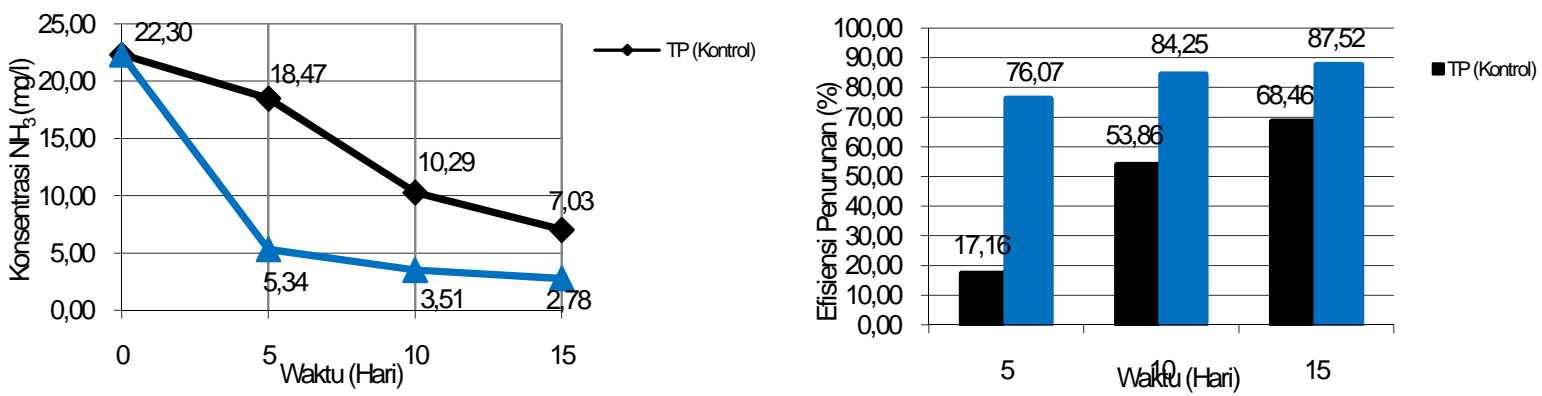

Gambar 9, 10 Penurunan konsentrasi $\mathrm{NH}_{3}-\mathrm{N}$

Hasil tersebut menunjukkan bahwa penurunan amoniak nitrogen (sebagai Nitrogen) terjadi pada tanpa pengolahan (Kontrol) meskipun efisiensi penurunannya kecil dibandingkan dengan Pengolahan Constructed Wetland, yaitu berturut turut pada waktu tinggal 5, 10 dan 15 hari adalah $17,16 \%$; 53,86\% dan 68,46\%, sedangkan pengolahan efisensi penurunan amoniak pada Constructed Wetland dengan tumbuhan Typha angustifolia (VSF-CW + Typha) pada waktu tinggal 5, 10 dan 15 hari, yaitu berturut - turut $76,07 \%$; 84,25\% 87,52\%. Dari hasil tersebut peningkatan penurunan amoniak mengalami peningkatan seiring dengan bertambahnya waktu tinggal. Hal ini dikarenakan penurunan senyawa nitrogen dilakukan oleh bakteri melalui proses amonifikasi, nitrifikasi, denitrifikasi juga terjadi melalui volatilisasi ion amonium $\left(\mathrm{NH}_{4}^{+}\right)$menjadi gas $\mathrm{NH}_{3}$, sedimentasi dan penyaringan, adsorbsi ion amonium kedalam sedimen organik dan inorganik melalui pertukaran ion positif. (Liehr, 2000).

Pada pengolahan air limbah industri kerupuk dengan Constructed Wetland dengan tumbuhan Typha angustifolia terjadi karena adanya penyerapan nitrogen oleh tumbuhan (Typha angustifolia), meskipun menurut Gersberg, 1985 menyatakan bahwa penghilangan senyawa nitrogen secara langsung oleh tumbuhan rawa relatif kecil, namun peran tumbuhan rawa mempunyai peran yang tidak langsung tetapi sangat penting dalam proses penghilangan nitrogen, yaitu menjadi tempat pelengketan organisme mikro dan memasok oksigen melalui rizosfer sehingga mendukung pertumbuhan bakteri aerob. Sementara itu senyawa amoniak $\left(\mathrm{NH}_{3}\right)$ dan ion amonium $\left(\mathrm{NH}_{4}{ }^{+}\right)$yang terbentuk melalui penguraian oleh bakteri dalam proses amonifikasi akan diasimilasikan oleh tumbuhan menjadi berbagai bentuk senyawa organik. (Singleton, 1995).

Menurut Hidayat (2006 ) bahwa batang, cabang, dan daun tumbuhan akuatik yang berada di dalam genangan air akan memperluas area mikroorganisme melekat. Di bawah permukaan substrat pasir dan kerikil yang tergenang, akar tumbuhan mengeluarkan oksigen sehingga akan terbentuk zona akar dan zona oksigen, terjadi absorbsi nitrogen dan unsur pencemar untuk pertumbuhan tumbuhan.

\subsection{Penurunan Sulfida}

Berdasarkan pengujian konsentrasi awal hidrogen sulfide $\left(\mathrm{H}_{2} \mathrm{~S}\right)$ adalah sebesar 4,47 mg/l. Konsentrasi $\mathrm{H}_{2} \mathrm{~S}$ tersebut mengalami penurunan, yaitu pada tanpa pengolahan (Kontrol), menjadi $1,93 \mathrm{mg} / \mathrm{l} ; 1,05 \mathrm{mg} / \mathrm{l}$ dan $0,5 \mathrm{mg} / \mathrm{l}$ pada waktu pengolahan berturut - turut 5, 10 dan 15 hari. Sedangkan pada sistem pengolahan Vertical Subsurface Flow Constructed Wetland dengan tumbuhan Typha angustifolia (VSF-CW+Typha), $\mathrm{H}_{2} \mathrm{~S}$ dapat dirunkan sampai pada konsnetrasi 0,24 $\mathrm{mg} / \mathrm{l}$ (5 hari), 0,04 mg/l (10 hari) dan 0,008 mg/l (15 hari). Penurunan konsentrasi $\mathrm{H}_{2} \mathrm{~S}$ tersaji pada gambar 11, sebagai berikut : 

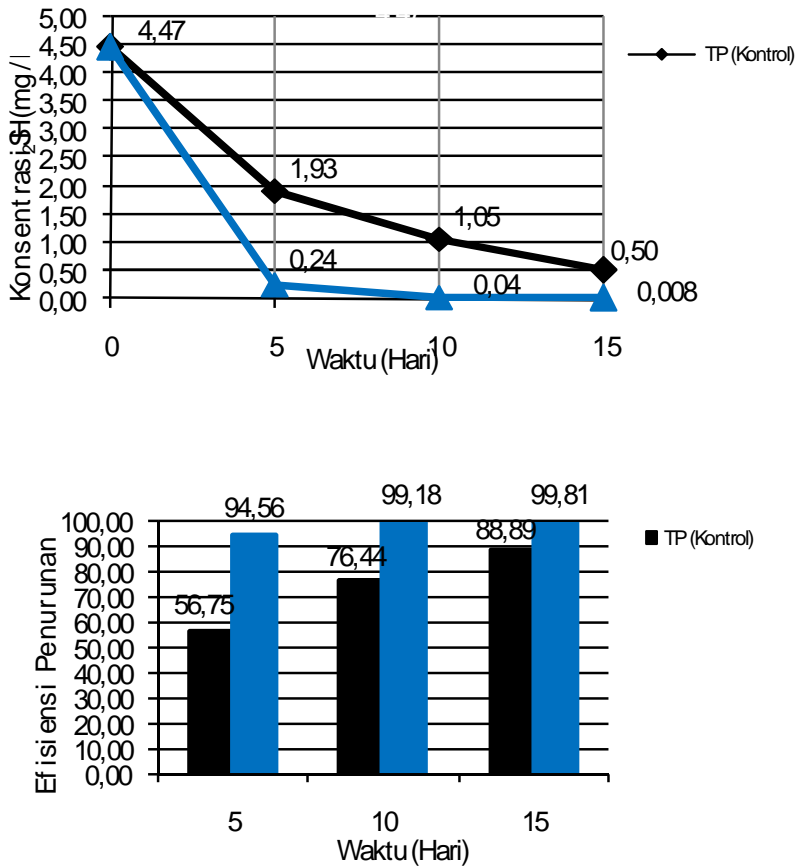

Gambar 11, 12 Penurunan konsentrasi $\mathrm{H}_{2} \mathrm{~S}$

Dari hasil gambar 12 diatas menunjukkan bahwa adanya penurunan hidrogen sulfida pada air limbah industri kerupuk pada semua perlakuan. Hal ini diakibatkan karena terjadinya oksidasi hidrogen sulfida $\left(\mathrm{H}_{2} \mathrm{~S}\right)$ yang melibatkan bakteri menghasilkan air dan belerang bebas (S) dengan reaksi sebagai berikut:

$$
2 \mathrm{H}_{2} \mathrm{~S}+\mathrm{O}_{2} \quad 2 \mathrm{~S}+2 \mathrm{H}_{2} \mathrm{O} \quad \ldots \ldots \ldots \ldots \ldots \text { (1) }
$$

Beberapa bakteri yang dapat mengoksidasi senyawa sulfur adalah Thiobacillus thioxidans dan Thiobacillus feroxidans. Kedua mikroorganisme ini mengoksidasi $\mathrm{H}_{2} \mathrm{~S}$ dan membentuk sulfur elemen yang disimpan dalam selnya (Edmons, 1978).

Penurunan $\mathrm{H}_{2} \mathrm{~S}$ pada perlakuan tanpa pengolahan (kontrol), yaitu berturut turut pada waktu tinggal 5, 10 dan 15 hari sebesar 56,75\%; $76,44 \%$ dan $88,89 \%$; yang disebabkan karena media yang digunakan untuk menampung air limbah memiliki kedalaman $20 \mathrm{~cm}$, sehingga sinar matahari dan oksigen dari udara dapat masuk kedalam air limbah, dengan demikian penguraian zat organik yang terkandung pada air limbah dapat terjadi secara aerob oleh bakteri aerob dan untuk timbulnya gas sulfida sangat kecil, karena gas sulfida akan terjadi akibat proses anaerob.

Efisiensi penurunan $\mathrm{H}_{2} \mathrm{~S}$ pada Constructed Wetland dengan tumbuhan Typha angustifolia (VSF-CW + Typha), yaitu 94,56\% ( 5 hari), 99,18\% (10 hari) dan 99,81\% (15 hari). Hal ini dikarenakan pada Constructed Wetland tersebut diperlakukan pengoperasian sirkulasi air limbah secara intermiten selama 30 menit dengan menggunakan pompa peristaltik 6 kali sehari, sehingga oksigen di udara akan semakin banyak yang masuk ke dalam air limbah yang kemudian menjadi oksigen terlarut dan digunakan untuk menguraikan bahan organik pada limbah oleh bakteri aerob juga dimungkinkan adanya pelepasan oksigen oleh akar tumbuhan rawa menyebabkan air limbah disekitar rambut akar memiliki kadar oksigen terlarut yang lebih tinggi dibandingkan dengan air yang tidak ditumbuhi tumbuhan air, sehingga memungkinkan organisme penguarai aerob dapat hidup. 


\section{KESIMPULAN} bahwa :

Dari hasil penelitian diatas dapat disimpulkan

1) Konsentrasi TSS, $\mathrm{BOD}_{5}, \mathrm{COD}$, Amoniak $\left(\mathrm{NH}_{3^{-}}\right.$ $\mathrm{N})$, dan Sulfida $\left(\mathrm{H}_{2} \mathrm{~S}\right)$ yang terkandung pada limbah cair industri kerupuk dapat diturunkan dengan sistem pengolahan Subsurface Flow Constructed Wetland dengan tanaman Typha angustifolia dengan persentasi penurunun akan semakin tinggi seiring dengan bertambahnya waktu tinggal;

2) Sistem pengolahan Subsurface Flow Constructed Wetland dengan tanaman Typha angustifolia memiliki penurunan konsentrasi zat pencemar, yaitu pada 5, 10 dan 15 hari adalah berturut turut untuk TSS $(73,78 \%$; $77,18 \% ; 84,71 \%) ; \quad$ BOD $_{5}(85,83 \% ; 90,33 \%$; 94,17\%); COD (86,94\%; 90,65\%; 94,87\%); Amoniak $\left(\mathrm{NH}_{3}-\mathrm{N}\right)(76,07 \% ; 84,25 \% ; 87,52 \%)$; Sulfida $\left(\mathrm{H}_{2} \mathrm{~S}\right)(94,56 \% ; 99,18 \% ; 99,81)$;

\section{DAFTAR PUSTAKA}

Alaerts dan Santika, 1987. Metode Penelitian Air. Usaha Nasional. Surabaya

Edmons, P.1978. Microbiology an Environmental Perspective. Collier Macmillan, London

Effendi, H. 2003. Telaah Kualitas Air bagi Pengelolaan Sumber Daya dan Lingkungan Perairan. Kanisius. Yogjakarta

Evasari Johanna., 2012. Pemanfaatan Lahan Basah Buatan dengan Menggunakan Tanaman Typha Latifiola Untuk Mengolah Limbah Cair Domestik. Skripsi. Program Studi Teknik Lingkungan, Universitas Indonesia, Jakarta

Gersberg, RM., Elkins, B.V., Lyons, S.R.,Goldman, C.R., 1985. Role of Aquatic Plants in Wastewater Treatment by Artificial Wetlands. Water Resources, (20), 363-367

Hammer, J. J, 1996. Water and Waste Water Technology. John Wiley and Sons. New York

Hammer, D.A. and Bastian, R.K., 1989. Wetland Ecosystem : Natural Water Purifiers

Hidayah Euis Nurul dan Wahyu Aditya., 2010. Potensi dan pengaruh tanaman pada pengolahan air limbah domestik dengan sistem constructed wetland. Envirotek 2 (2), 11-18

Khiatuddin, M., 2003. Melestarikan sumber daya air dengan teknologi rawa buatan. Gajah Mada University Press, Yogyakarta

Leady, B., 1997, Constructed subsurface flow wetlands for wastewater treatment. Purdue University

Liehr, S.K, et al., 2000. Constructed Wetlands Treatment of High Nitrogen Landfill Leachate. Water Environment Research Foundation. Alexandria. Virginia

Metcalf \& Eddy, 2003. Wastewater Engineering: Treatment and Reuse. Fourth Edition. McGraw-Hill International. New York

Metcalf \& Eddy, 1993, Wastewater Engineering Treatment Disposal Reuse. McGraw-Hill Comp

Prunster,m R.W., 1940. The control of cumbungi (Typha spp.) in irrigation channels, J. Sci. Industr. Res. 13: 1-6

Rump dan Krist, H. H and Krist, H. 1992. Laboratory Manual for The Examination of Water, Wastewater and Soil. Germany. Weinheim

Singleton, P. 1995. Bacteria in Biology, Biotechnology and Medicine 3rd ed. John Wiley and Sons. Chichester

Soemirat, S. J, 1994.Kesehatan Lingkungan. Gajah Mada University Press. Yogyakarta

Stowell, R., Ludwig, R.,Colt, J., dan Tchobanoglous, G., 1980. Toward The Rational Design of Aquatic Treatment System. Dep. Of Civil Eng. University of California. Davis

Supradata, 2005. Pengolahan limbah domestik menggunakan tanaman hias cyperus alternifolius dalam ssstem lahan basah aliran permukaan (SSF wetland). Tesis Magister Lingkungan

Tangahu, B.V. dan Warmadewanthi, I.D.A.A., 2001. Pengelolaan limbah rumah tangga dengan memanfaatkan tanaman cattail (typha angustifolia) dalam sistem constructed wetland. Purifikasi, 3 (3), 127132

USDA, NRCS, 2006. National Plant Data Center \& Idaho Plant Materials Center 
Vymazal, J., 2002. The Use of Sub-surface Constructed Wetland for Wastewater treatment in The Czech Republic : 10 years experience. Ecological Engineering, 18 (5).

Wood A., 1995. Constructed wetlands in pollution control: fundamentals to their understanding. Wat. Sci. Tech. 32 (3), 2129
Yeo, R.R., 1964. Life history of common cattail, Weeds 12: 284Cristes, RW and Tchobanoglaus, 1998. Small and Decentralized Wastewater Management System. McGraw-Hill, New York 